\title{
A European Future for Kosovo: Is the EU Losing its Grip?
}

\author{
Valeska Esch*
}

\begin{abstract}
Equipped with EULEX, the largest civilian mission ever launched by the EU, the executive powers of the formerly double-hatted EUSR/ICR, the European Commission Liaison Office, and strong support in the Kosovar population for European integration, the EU seems in an ideal position to assert influence over Kosovo. However, the EU has thus far had difficulties finding a coherent approach to Kosovo leaving its European future blurry. Therefore, this paper will discuss the EU-engagement in Kosovo, its European integration perspective and its exclusion from the visa liberalisation process of the Western Balkan countries with a particular focus on the difficulties arising from the disunity among member states regarding Kosovo's status. Finally, an outlook will be given on how the EU might nevertheless be able to raise its profile in Kosovo as a mediator between Belgrade and Pristina.
\end{abstract}

Keywords: European Union, Kosovo, EULEX

Europäische Union, Kosovo, EULEX

\section{Introduction}

$\mathrm{O}$ ver the past months, Kosovo has been hitting the negative headlines: the breakdown of the coalition, early elections, reports of election fraud, cases of organ trafficking, and the allegations against Kosovar leaders, in particular Kosovo's Acting Prime Minister Hashim Thaçi, of their involvement in organised crime and war crimes. At the same time, the countries of the Western Balkans are integrating into the European Union (EU), leaving Kosovo no longer in the EU's backyard but on its doorstep. Regardless of its division on Kosovo's status ${ }^{1}$ and the unsettled question within the Union of whether to treat Kosovo as an independent state or as part of the territory of the Republic of Serbia, the EU has committed substantial resources to Kosovo: the European Union Rule of Law Mission (EULEX) is the largest civilian EU mission; the EU has had a European Union Special Representative (EUSR) in Kosovo, who used to also be the International Civilian Representative (ICR); and the European Commission (EC) has opened a Liaison Office in Kosovo, in order to provide guidance to the authorities in Pristina, particularly with regard to European integration.

Due to the amount of resources allocated to Kosovo and the leverage of eventual EU membership, Kosovo has been considered a litmus test for the EU's Common Foreign and Security Policy (CFSP). However, its internal division on Kosovo's status continues to impair the EU's position. The disagreement of the EU member states on a basic question like that of statehood forces the EU to try to remain neutral on the question of status in its engagement despite the national policies of the majority of 22 recognising member states, leaving Kosovo-Albanians sceptical of full EU support. Moreover, although the EU continues to emphasise the European perspective of Kosovo, ${ }^{2}$ the question of how it can

* Valeska Esch works as a Program Officer in the Leadership Program of the Aspen Institute Germany with a focus on Southeast Europe. She joined Aspen in February 2009 as a Program Assistant. She graduated in Political Science, International Law, English Language and Literature at the Rheinische Friedrich-Wilhelms-Universität Bonn with a focus on Security Policy, the European Union, and Southeast Europe and wrote her Magister thesis on the EU's engagement in Kosovo. This article has successfully undergone a doubleblind peer-review process.

1 Cyprus, Greece, Romania, Slovakia and Spain have not recognised Kosovo.

2 Officially called "Kosovo under UN Security Council Resolution 1244" in all official EU documents. eventually become a member of the $\mathrm{EU}$ without recognition by Serbia as another potential candidate for EU membership as well as five EU countries remains unanswered, with the issue of Cyprus serving as a negative example.

Kosovo has thus far been excluded from visa liberalisation for the region suggesting that Kosovo is being left behind in the $\mathrm{EU}$ integration process, and the continual negative headlines contribute to the impression that the EU might be losing its grip. For this reason, this paper provides an overview over the EU engagement, including the limitations due to the status issue. Since the setup of the EU engagement is based on the Ahtisaari Plan that has not been adopted by the United Nations Security Council (UNSC), the mandates and tasks of EULEX, the EUSR and the ICR as well as the remaining presence of UNMIK will be presented briefly.

Finally, an outlook will be given on the potential role of the $\mathrm{EU}$ in the context of two pressing issues: a) the report on the "Inhuman treatment of people and illicit trafficking in human organs in Kosovo"3 presented by Dick Marty, Rapporteur on Legal Affairs and Human Rights for the Council of Europe (CoE) and adopted by the Parliamentary Assembly of the $\mathrm{CoE}$ (PACE) in Resolution 1782 (2011) inviting EULEX to investigate the allegations; ${ }^{4}$ and $b$ ) the EU's role as a facilitator of direct talks between Belgrade and Pristina. This paper concludes that over the past months the pressure on the EU to deliver on Kosovo has risen substantially. EULEX will need to increase its efforts in investigating and prosecuting high-level figures allegedly involved in organised crime and war crimes. Making use of the leverage of EU integration that it holds over Belgrade and Pristina, the EU needs to push for compromises in the negotiations between Belgrade and Pristina that can eventually lead to a negotiated solution that will at least allow for a mutually accepted co-existence. After all, any agreement between Belgrade and Pristina on the future of Kosovo can

3 Cf. Dick Marty: Inhuman treatment of people and illicit trafficking in human organs in Kosovo, Strasbourg, 07 January 2011 (Doc. 12462), from: http://assembly.coe.int/Documents/WorkingDocs/Doc11/EDOC12462.pdf $(3 / 2 / 2011)$.

4 Cf. Council of Europe Parliamentary Assembly: Investigation of allegations of inhuman treatment of people and illicit trafficking in human organs in Kosovo, Strasbourg, 25 January 2011 (Resolution 1782 (2011)), from: http:// assembly.coe.int/Mainf.asp?link=/Documents/AdoptedText/ta11/ERES1782 $\operatorname{htm}(3 / 2 / 2011)$ 
fundamentally help the EU to regain a common position on Kosovo.

\section{The Development of Different Legal Realities on the Ground}

The UNSC Resolution 1244 (1999) ended the Kosovo-War in 1999 and placed Kosovo under the United Nations Interim Administration Mission in Kosovo (UNMIK). In 2006/2007, Martti Ahtisaari, Special Envoy of the UN Secretary General on Kosovo's Future Status, tried to negotiate a final status of Kosovo between Belgrade and Pristina. After these negotiations failed, he drafted a "Comprehensive Proposal for the Kosovo Status Settlement" 5 , the so-called Ahtisaari Plan, which UN Secretary General Ban Ki-moon forwarded to the UNSC for adoption in March 2007.

The Plan envisaged internationally supervised independence for Kosovo with continued presence of the North Atlantic Treaty Organization (NATO), an EU rule of law mission to replace UNMIK, an EUSR to exercise direction over the EU mission, and an ICR with executive powers to oversee the implementation of the Ahtisaari Plan. The EUSR and the ICR were intended to be vested in the same person. However, the Ahtisaari Plan was not adopted by the UNSC. Final efforts for negotiating a status settlement by a Troika consisting of the EU, Russia and the USA failed due to the irreconcilable positions of Belgrade and Pristina: while Belgrade, with Russian support, refused to agree to any solution exceeding the autonomy of Kosovo within Serbia, Pristina, strongly supported by the Quint countries ${ }^{6}$, was unwilling to accept anything short of independence. Kosovo therefore unilaterally declared independence on 17 February 2008. In order to gain international support, the authorities in Pristina constitutionally bound themselves to the implementation of the Ahtisaari Plan. ${ }^{7}$ Still, the fact that the Plan was not authorised by the UNSC was significant: a legal basis for an international presence as envisaged in the Plan was not given for countries that did not recognise Kosovo. The consequences for EULEX and the ICR/EUSR will be outlined below.

\subsection{EULEX}

In light of Kosovo's looming unilateral declaration of independence, the EU launched EULEX and appointed Peter Feith EUSR prior to the declaration, ${ }^{8}$ despite its imminent division over the issue of recognition. Nevertheless, only

5 Ban Ki-moon: Comprehensive Proposal for the Kosovo Status Settlement. Letter dated 26 March 2007 from the Secretary-General addressed to the President of the Security Council. Addendum, New York, 26 March 2007 (S/2007/168/Add.1), from: http://www.unosek.org/docref/Comprehensive proposal-english.pdf $(2 / 2 / 2011)$.

6 Countries of the so-called 'Quint' are: France, Germany, Italy, the United Kingdom, and the USA.

7 Cf. Constitution of the Republic of Kosovo, Pristina, 15 June 2008, Art. 143, from: http://www.assembly-kosova.org/common/docs/Constitution $1 \% 20$ of \%20the\%20Republic\%20of\%20Kosovo.pdf (27/1/2011).

8 Cf. Council of the European Union: Kosovo: Council Establishes an EU Rule of Law Mission, Appoints an EU Special Representative, Brussels, 16 February 2008 (6613/08 (Presse 43)), from: http://www.consilium.europa.eu/uedocs/ cms_Data/docs/pressdata/en/gena/98768.pdf (3/2/2011). the countries recognising Kosovo as an independent state considered the commitment to the Ahtisaari Plan in the Kosovar constitution a sufficient legal basis for the deployment of EULEX. Moreover, EULEX could not have been deployed in areas with a Kosovo-Serb majority without support from Belgrade, which insisted on the authority of UNMIK.

Therefore, the UN negotiated a six-point-plan with Belgrade, which included EULEX's deployment under the umbrella of UNMIK in accordance with Resolution 1244. This compromise was finally accepted by the UNSC in November 2008; however, it was negotiated without the approval of Kosovo-Albanians, who no longer considered Resolution 1244 binding. ${ }^{9}$ The compromise thus demonstrates an agreement of all involved actors regarding a selective perception of the situation: whereas Kosovo-Albanians consider EULEX the successor of UNMIK, deployed to assist their young state in the establishment of rule of law as envisaged in the Ahtisaari Plan, non-recognising states and especially Belgrade consider EULEX part of UNMIK as an interim administration mission on Serb territory. This has led to two parallel legal realities on the ground for the sake of stability, which will be explained below. Moreover, it resulted in controversy over the chain of command of EULEX: deployed under the umbrella of UNMIK, EULEX is deployed under the overall authority of the UN; however, the Council of the European Union decision to deploy EULEX established the Political and Security Committee (PSC) under the responsibility of the Council as providing unified command ${ }^{10}$ with the EUSR providing political guidance to the mission. ${ }^{11}$ Despite a lack of clarity on the chain of command of EULEX, the EU was finally able to start its work and declare initial operational capability in December 2008.

EULEX consists of three components: justice (civil and criminal cases, including organised crime, corruption, inter-ethnic crimes, financial/economic crimes and missing persons), police (including operational matters, border policing, crime and police administration) and customs. In recognition of the principle of local ownership, EULEX is designed to assist the local authorities in the establishment of rule of law through a focus on monitoring, mentoring and advising the local institutions (MMA approach). Nevertheless, EULEX has executive functions in the fields of crime and war crimes, fight against corruption, riot control, and it can reverse or annul operational decisions taken by locals. ${ }^{12}$

The justice component, for example, consists of EULEX judges and prosecutors, who work closely and often in mixed teams with their Kosovar counterparts, in order to assist the local authorities to develop a justice system that is "free from political interference and adhering to internationally

9 For a detailed overview over the struggle for EULEX's mandate, cf. Martina Spernbauer: EULEX Kosovo: The Difficult Deployment and Challenging Implementation of the Most Comprehensive Civilian EU Operation to Date, in: German Law Journal, 11:8 (2010), pp. 776-84.; and Emily Haber: Primat der Stabilität, in: Internationale Politik, 7/8 (2009).

10 Cf. Council of the European Union: Council Joint Action on the European Union Rule of Law Mission in Kosovo, EULEX Kosovo, Brussels, 4 February 2008 (2008/124/CFSP, Official Journal of the European Union 2008/ L 112/19), Art. 11.1-2, from: http://www.eulex-kosovo.eu/en/info/docs/ JointActionEULEX_EN.pdf (2/2/2011).

11 Cf. ibid., Art. 8.8.

12 Cf. ibid., Art. 2-3. 
recognised standards and European best practices." ${ }^{13}$ Moreover, based on the "law on the jurisdiction, case selection and case allocation of EULEX judges and prosecutors in Kosovo" 14 and the guidelines for case allocation as established by the Assembly of the EULEX Judges, ${ }^{15}$ EULEX judges and prosecutors also act exclusively, inter alia in the fields of organized crime, war crimes, hate crimes and terrorism. ${ }^{16}$

However, EULEX is trapped between different legal codes, including UNMIK code, Yugoslav code and the Kosovo code. The decision on which legal code to apply is taken by the individual EU judges depending on recognition or non-recognition of Kosovo as an independent state. It is therefore a highly political decision, leading the EU's mission of providing legal security and "ensuring that these institutions are free from political interference"17 ad absurdum. This example reflects the political tightrope walk of EULEX between the parallel constitutional orders: on the one hand, EULEX is supposed to be status-neutral and is bound by Resolution 1244, on the other hand, following the MMA approach EULEX officials act jointly with their Kosovar counterparts, thereby operating as an integral part of the legal system of Kosovo, in close cooperation with the state authorities and on the basis of legislation passed by the Kosovo Assembly. ${ }^{18}$ Another example of the parallel constitutional orders is the Mitrovica District court in Kosovo's Serb-dominated north: the court is blocked by the procedural question of appointing judges, where Serbs do not agree to the seating of judges appointed under Kosovo law while Pristina insists on the appointment of judges under its legislation. EULEX has yet to find a solution to this deadlock and has, for the time being, failed to deploy sufficient EU judges to compensate for the lack of locals. ${ }^{19}$ Hence, while the creation of two parallel legal realities was the only way for the EU to agree on the launch of EULEX, its status-neutral deployment under Resolution 1244 "while at the same time building the key institutions of internal sovereignty (police, justice and customs) means squaring the circle."20

The EULEX police component also follows the approach of local ownership. EULEX police officers are co-located with their local counterparts and advise and assist the Kosovo Police while

13 Ibid., Art. 2.

14 Assembly of the Republic of Kosovo: Law on the Jurisdiction, Case Selection and Case Allocation of EULEX Judges and Prosecutors in Kosovo, Pristina, 1 March 2008 (Law No. 03/L-053), from: http://www.assembly-kosova.org/ common/docs/ligjet/2008_03-L053_en.pdf (4/6/2011).

15 The guidelines for case allocation in criminal and civil law as well as in criminal cases at the Kosovo Supreme Court can be found at: EULEX Kosovo: Assembly of the EULEX Judges, Pristina, from: http://www.eulex-kosovo.eu/ en/justice/assembly-of-the-eulex-judges.php (4/6/2011).

16 Cf. Assembly of the EULEX Judges: Guidelines for Case Allocation for EULEX Judges in Criminal Cases in District Courts, EULEX Kosovo, Pristina, 10 July 2008 , p. 1, from http://www.eulex-kosovo.eu/docs/justice/assembly/rules/ side-meny/02A.\%20GUIDELINES\%20FOR\%20CASE\%-20ALLOCATION\%20 pdf $(4 / 6 / 2011)$ and Assembly of the Republic of Kosovo: Law on the Special Protection Office of the Republic of Kosovo, Pristina, 13 March 2008 (Law No. 03/L-052), Art. 5, from: http://www.assembly-kosova.org/common/docs/ ligjet/2008_03-L052_en.pdf (4/6/2011).

17 Council of the European Union: Council Joint Action 2008/124/CFSP, Art. 2.; Cf. also Christopher S. Chivvis: EU Civilian Crisis Management. The Record So Far, Santa Monica 2010, pp. 37, 40.

18 Cf. Spernbauer: EULEX Kosovo, p. 783.

19 Cf. International Crisis Group: The Rule of Law in Independent Kosovo, p. 20.

20 Solveig Richter: Promoting Rule of Law, without State-building. Can EULEX Square the Circle in Kosovo?, in: Muriel Asseburg/Ronja Kempin (eds): The EU as a Strategic Actor in the Realm of Security and Defence? A Systematic Assessment of ESDP Missions and Operations, Berlin 2009, p. 34. at the same time retaining executive powers, especially in the fields of riot control or political interference. A success story of this approach has been the reintegration of Serb officers in the Kosovo Police (KP) after Kosovo's declaration of independence; however, Kosovo-Serbs do not serve under the chain of command of the police headquarters in Pristina but merely report to EULEX. ${ }^{21}$ Overall, aside from the difficult political and legal realities on the ground, EULEX and the local justice system have been criticised inter alia for a lack of resources and qualified personnel, especially for prosecution and judicial proceedings, and a lack of coordination and cooperation, in particular between the police and prosecution, leading to a large backlog of cases, lacking penal action, and the loss of evidence. ${ }^{22}$

\section{$2.2 \mathrm{ICR} / \mathrm{EUSR}$}

According to the Ahtisaari Plan, the International Steering Group (ISG) ${ }^{23}$ appoints the ICR after consultations with the EU, and "seek[s] United Nations Security Council endorsement of the appointment". ${ }^{24}$ With support of the International Civilian Office (ICO) the mandate of the ICR is to serve as the final authority to ensure the implementation of the Plan, including "corrective measures to remedy, as necessary, any actions taken by the Kosovo authorities that the ICR deems to be a breach of this Settlement, or seriously undermine the rule of law, or to be otherwise inconsistent with the terms or spirit of this Settlement". ${ }^{25}$ Moreover, EULEX has to consult the ICR in the appointment process of international judges and prosecutors, or in case the mission uses its executive powers. ${ }^{26}$ Finally, the ICR is responsible for the coordination of the international presence in the implementation of the Ahtisaari Plan. ${ }^{27}$ As envisaged in the Ahtisaari Plan, the ICR and the EUSR are supposed to be consolidated in the same person ${ }^{28}$ with the EUSR being responsible to exercise direction over EULEX. ${ }^{29}$

Since the Ahtisaari Plan was not adopted by the UNSC, the role of the ICR/EUSR has been controversial. As outlined above, the Kosovar institutions obligated themselves to implement the Plan, thereby accepting the authority of the ICR/EUSR. Thus, the ISG appointed Peter Feith, who had already been appointed EUSR, ICR. Since he lacks approval from the UNSC, however, the invitation from the Kosovar authorities serves as the sole legal basis for an ICR mandate - provided Kosovo's independence is recognised. Consequently, Serbs, supported by non-recognising states, consider the presence of the ICR

21 Cf. Richter: Promoting Rule of Law, pp. 40-1.

22 For a detailed overview on the situation in Kosovo cf. International Crisis Group: The Rule of Law in Independent Kosovo, Pristina/Istanbul/ Brussels, 10 May 2010 (Europe Report No204), from: http://www.crisisgroup. org/ /media/Files/europe/balkans/kosovo/204\%20The\%20rule \%20of\%20Law\%20in\%20Independent\%20Kosovo.ashx (3/2/2011); and Spernbauer: EULEX Kosovo, pp. 784-802.

23 The ISG consists of Austria, Belgium, Bulgaria, Croatia, the Czech Republic, Denmark, Estonia, Finland, France, Germany, Hungary, Ireland, Italy, Latvia, Lithuania, Luxembourg, the Netherlands, Norway, Poland, Slovenia, Switzerland, Sweden, Turkey, the United Kingdom and the United States of America.

24 Ban: Comprehensive Proposal, Art. 12.1.

25 Ibid., Annex IX, Art. 2c.

26 Cf. ibid., Art. 12-14, Annex IX, X, XI.

27 Cf. ibid., Art. 12.5, Annex IX, Art. 3.

28 Cf. ibid., Art. 12.1, Annex IX, Art. 2.3.

29 Cf. ibid., Art. 12.3, 12.4, Annex IX, Art. 2.3. 
and his activities illegal and reject any form of cooperation. ${ }^{30}$ Nevertheless, the ICR inter alia has been consulting the Kosovar authorities on legislation and the setup of institutions, and has appointed international officials, including judges to Kosovo's Constitutional Court, the Judicial Council and the Appeals Panel of the Supreme Court. ${ }^{31}$

The non-recognising member states of the EU only accepted Pieter Feith as the EUSR. The mandate of the EUSR concentrates on his advisory function for the Kosovo government, the coordination of EU activities in Kosovo, the insurance of consistency and cohesion of EU activities and political guidance to EULEX. ${ }^{32}$ As a result, the EU and EULEX cannot cooperate with the ICO/ICR officially, while the ICO is cementing Kosovo's independence and supports Kosovo's preparations for EU integration. Nevertheless, EULEX has cooperated with the ICR at least in some instances, for example in the context of the appointment of international members proposed by EULEX to the Judiciary Council, or when the ICR has to consent to international judges and prosecutors selected by EULEX prior to their appointment. ${ }^{33}$ This again reveals the selective perception within the two parallel legal realities, culminating in Peter Feith, who as ICR/EUSR was on the one hand supposed to be statusneutral and on the other hand supposed to support Kosovo's independence and the implementation of the Ahtisaari Plan.

In recognition of this contradictory position, the EU has been discussing the decoupling of the mandates of EUSR and ICR. After the expiration of Peter Feith's mandate as EUSR on 30 April 2011, the EU appointed Fernando Gentilini as temporary EUSR in Kosovo in order to "prepare for a strengthened and long-term EU presence in Kosovo" 34 . However, given the EU's division on Kosovo's status and the implications this division has for the understanding of the current situation as outlined above, compromise on the structure of a consistent future EU presence in Kosovo has yet to be found. While the step of decoupling the ICR from the EUSR has resolved the contradictory mandate of Peter Feith, the above-mentioned issues of cooperation between EULEX and the ICR/ICO as well as controversies over status-neutral EU engagement and deployment of EULEX under Resolution 1244/UNMIK remain.

\subsection{UNMIK}

A further component of the different legal realities on the ground is UNMIK. As mentioned above, for non-recognising

30 Cf. Christian Schaller: Die Sezession des Kosovo und der völkerrechtliche Status der internationalen Präsenz, in: Archiv des Völkerrechts, 46 (2008), pp. 162-5.

31 Cf. International Civilian Office Kosovo: Implementation of the Comprehensive Settlement Proposal - State of Implementation, Pristina, 14 December 2010, from: http://www.ico-kos.org/ico/data/Image/15122010 Matrix_FINAL___Eng.pdf (3/2/2011).

32 Cf. European Council: Council Decision extending the mandate of the European Union Special Representative in Kosovo, 11 August 2010 (2010/446/ CFSP, Official Journal of the European Union 2010/L 211/36), Art. 3, from: http://www.eusrinkosovo.eu/d/LexUriServ11082010.pdf (2/2/2011).

33 Cf. International Civilian Office Kosovo: Implementation of the Comprehensive Settlement, p. 10.

34 Cf. European Union: Statement by the High Representative, Catherine Ashton, on the appointment of Fernando Gentilini as EU Special Representative in Kosovo, Brussels, 6 May 2011 (A 176/11), from: http://www.consilium.europa. eu/uedocs/cms_data/docs/pressdata/EN/foraff/121881.pdf (4/6/2011). countries and the status-neutral deployment of EULEX, UNSC Resolution 1244 and therefore UNMIK is still in place. According to Resolution 1244, the Head of the Mission, the Special Representative of the UN Secretary-General (SRSG), has executive powers and is responsible for the coordination of the international civilian presence in Kosovo, including EULEX. His mandate is therefore similar to that envisaged for the ICR/EUSR, who according to the Ahtisaari Plan would have replaced the SRSG.

While EULEX has taken over the majority of UNMIK's rule of law activities, UNMIK facilitates relations between non-recognising countries and Kosovo-Serbs who refuse to address the Kosovar authorities directly on the one hand, and Pristina on the other; it handles document certifications for countries not recognising documents issued by Pristina and facilitates Kosovo's participation in regional fora, in which Kosovar participation would otherwise not be possible. Finally, UNMIK monitors political developments in Kosovo and is actively working with its different communities. ${ }^{35}$ Overall, as mentioned above, the intention was for the structures of the Ahtisaari Plan to replace UNMIK. Due to a lack of international recognition of Kosovo and therefore the validity of the Ahtisaari Plan, several duplicate structures have been established - one set for recognising countries, the other set for non-recognising countries.

\section{The Promise of a European Future for Kosovo}

Ever since the Thessaloniki Summit in June 2003 the EU has strongly confirmed the European perspective for the countries of Southeastern Europe including Kosovo. Kosovo has been participating in the Stabilisation and Association Process (SAP) through the SAP Tracking Mechanism (STM) since 2003, which was transformed into the SAP Dialogue (SAPD) in 2009. Moreover, Kosovo has been involved in a European Partnership Agreement since 2004. This integration perspective can serve as a strong reform incentive for Kosovo, especially since 86.8 percent of the population are in favour of joining the EU. ${ }^{36}$ It puts the EU in the position of being able to apply its principle of conditionality, with the overall goal of bringing Kosovo without prejudice to its status - closer to fulfilling the criteria for signing a Stabilisation and Association Agreement (SAA).

In order to serve as an incentive, however, the perspective needs to be tangible. Today, all countries in the SAP have signed SAAs, with Kosovo being excluded. Kosovo is not only far from reaching European standards, the controversy about its status further hampers its progress and the question how Kosovo could someday join the EU as long as the Union remains divided on its status is yet to be answered.

Moreover, in contrast to its neighbouring countries which benefit from visa-free travel to Schengen countries, the EU

35 Cf. United Nations Security Council: Report of the Secretary-General on the United Nations Interim Administration Mission in Kosovo, New York, 3 May 2011 (S/2011/281), from http://www.unmikonline.org/SGReports-/UN_Sec Gen Kosovo Report 052011.pdf (1/6/2011).

36 Cf. Gallup Balkan Monitor: Insights and Perceptions: Voices of the Balkans. Survey Data. Vote in EU referendum, Brussels 2010, from: http://www.balkanmonitor.eu/index.php/dashboard (2/2/2011). 
has not officially opened a visa dialogue with Kosovo, stating that Kosovo first had to implement a series of reforms, inter alia the signing of readmission agreements and their effective implementation, and the enhancement of the security of its borders and the issuance of its documents. ${ }^{37}$ In contrast, the only precondition for the start of a visa dialogue for its neighbouring countries was the successful handling of readmissions, ${ }^{38}$ which Kosovo has been doing according to the EC's progress report 2010. ${ }^{39}$

At the same time, the Schengen visa liberalisation for Taiwan suggests that the status issue cannot be the reason for withholding Kosovo a visa dialogue. On the other hand, concerns about organised crime and illegal immigration play an important role, and the high numbers of asylum seekers in Western European countries from Western Balkan countries following their visa liberalisation have raised further concerns. ${ }^{40}$ Nonetheless, sending the signal that " " $[\mathrm{s}]$ trict but fair' [...] does not play a considerable role" 41 by raising the bar for reforms prior to starting a dialogue might seriously undermine the credibility of the incentive of European integration. In turn, a visa roadmap could provide a common agenda for cooperation between EULEX and Pristina and could serve as a strong incentive for implementing reforms, as it is a goal that all citizens embrace. Given the even greater reform demands for signing an SAA, a visa roadmap currently is the most tangible incentive.

\section{Outlook}

Three years after Kosovo's declaration of independence and the EU's acceptance of responsibility for Kosovo's future, the EU seems in over its head. As if institution-building and the promotion of rule of law in the post-conflict situation of a society with extensive clan structures was not difficult enough, the EU remains trapped between the implementation of the Ahtisaari Plan and its status-neutral engagement. However, the EU is in a unique position to not only assert influence over Pristina but also over Belgrade and Tirana, due to their sole common goal: EU membership. The visa roadmaps for the countries of the Western Balkans have demonstrated that the application of strict conditionality with distinct guidelines and a clear goal can in fact serve as a strong incentive for reforms. Moreover, the recent arrest and extradition to the International Criminal Tribunal for the former Yugoslavia (ICTY) of Bosnian Serb

37 Cf. European Commission: Communication from the Commission to the European Parliament and the Council: Kosovo - Fulfilling its European Perspective, Brussels, 14 October 2009 (COM (2009) 5343), p. 6, from: http:// www.delprn.ec.europa.eu/repository/docs/kosovo_study_en.pdf (4/6/2011).

38 Cf. European Stability Initiative: Isolation Confirmed. How the EU is undermining its interests in Kosovo, Berlin/Brussels/Pristina, 22 November 2010, pp. 4, from: http://www.esiweb.org/pdf/esi_document_id_119.pdf (30/1/2011).

39 Cf. European Commission: Kosovo 2010 Progress Report, Brussels, 9 November 2010 (SEC(2010)1329), p. 51, from: http://ec.europa.eu/enlargement/pdf/key documents/2010/package/ks_rapport_2010_en.pdf (30/1/2011).

40 European Commission: EU Visa policy: ensuring legal certainty and preventing abuse, Brussels, 24 May 2011 (MEMO/11/328), from http://europa. $\mathrm{eu} / \mathrm{rapid} /$ pressReleasesAction.do?reference=MEMO/11/328\&format=-PDF\&a ged $=0 \&$ language $=$ EN\&guiLanguage $=$ en $(4 / 6 / 2011)$.

41 Gunda Schumann: Visa Liberalisation for Citizens of Kosovo. A Critical Analysis of the Current State of Play and Future Perspectives, in: Südosteuropa Mitteilungen, 4-5 (2010), p. 31. wartime General Ratko Mladić by Belgrade has signaled that EU conditionality can influence difficult political decisions. For this reason, the report by Dick Marty and the EU's role as a facilitator of direct talks between Belgrade and Pristina can be a chance for the EU to raise its profile in Kosovo and live up to the responsibility it has accepted.

\subsection{All Eyes on EULEX}

Organised crime in Kosovo has always been a major challenge for EULEX and it has repeatedly been reported that crime networks cut high into the Kosovar political and business elite. Allegations against members of the political elite in Kosovo have surfaced again with the report and resolution adopted in PACE on 25 January 2011. The report drafted by Marty identifies Thaçi as the "boss" 42 of the so-called Drenica Group, a criminal group that inter alia has allegedly been in control of the trade of heroin and other narcotics, responsible for assassinations, beatings, and detentions as well as the trafficking of organs extracted from prisoners during and after the war. Moreover, the report links further senior officials of Thaçis Democratic Party of Kosovo (PDK) to the Drenica Group, some of whom have already been subjects to investigations by UNMIK, the International Criminal Tribunal for the former Yugoslavia (ICTY) and EULEX. However, nobody was sentenced. The report partly draws back on and is in line with previous findings of several national intelligence services and NATO, which have never been published. ${ }^{43}$

Although the report admits that investigations and prosecutions are extremely difficult due to intimidated witnesses and strong loyalty within the clan structures of criminal organisations in Kosovo, ${ }^{44}$ it also criticises a lack of political will in the international community and a lack of cooperation on behalf of the authorities in Kosovo and Albania. ${ }^{45}$ Nonetheless, the resolution adopted by PACE invites EULEX to "persevere with its investigative work, without taking account of the offices held by possible suspects" 46 . Consequently, Belgrade has been trying to transfer the responsibility for an investigation to the UN, and EULEX has opened a preliminary investigation and called upon all relevant actors to present their evidence. ${ }^{47}$ Thaçi, in contrast, whose PDK won the controversial elections on 12 December 2010, has formed a new government under his leadership. He presents the report as a "fabricated slander" 48 against all Albanians and against Kosovo as an independent state.

Overall, dismantling the allegedly criminal structures in parts of Kosovo's political elite needs to be a top priority for EULEX, as this is an integral part of the mission. Moreover, increasingly dealing with war crimes committed not only by

\footnotetext{
42 Marty: Inhuman treatment of people, p. 14.

43 Cf. ibid., p. 14-6.

44 Cf. ibid., p. 25.

45 Cf. ibid., pp. 6-9.

46 Council of Europe Parliamentary Assembly: Resolution 1782 (2011), para 19.2 .

47 Cf. EULEX Kosovo: Press Release: EULEX statement on Council of Europe report into human organ trafficking, Pristina, 28 January 2011, from: http:// www.eulex-kosovo.eu/en/pressreleases/0119.php.

48 EUobserver: Kosovo PM interview: organ trafficking report is 'monstrous' slander, Brussels, 10 January 2011, from: http://euobserver.com/9/31613 (20/1/2011).
} 
Serbian forces (which has already been widely acknowledged) but also by former members of the Kosovo Liberation Army (KLA) can contribute to conveying a more balanced picture of what happened during the war - not in order to question the legitimacy of Kosovo-Albanians' desire for independence from Serbia as readily stated by Albanians, but in order to begin establishing the truth as a basis for reconciliation and dialogue. The EU therefore needs to take a clear stance on a truthful coming to terms with the past, regardless of the fact that this is a sensitive issue in significant parts of the Kosovar society, as many former KLA members are considered war heroes. It has been doing so with Belgrade despite strong criticism in parts of the Serb society and it needs to apply the same principles to Kosovo regardless of the risk of further losing popularity. Just as the extradition of Ratko Mladić and Goran Hadžić to the ICTY has been expected from Belgrade on its path to EU integration, it should be expected from Pristina and Tirana to support EULEX's efforts. However, given the outstanding role of the USA in Kosovo ever since the NATO intervention ending war in 1999, the EU will need full US support to make very clear that the only way to much-aspired Euro-Atlantic integration is through the establishment of truth.

It can therefore only be hoped that the EU will end its "hesitancy to push [...] cases too far, for fear of destabilizing the political balance in Pristina." ${ }^{49}$ EU member states need to find the political will to commit the necessary resources and political support to EULEX, in order to provide it with the means necessary to investigate at the highest political level, including the establishment of trust from witnesses and a secure witness protection programme that, if necessary, enables them to resettle to EU member states or even the USA. Moreover, the EU needs to use its leverage of EU integration over Albania to enhance its cooperation with the investigations. If, however, the allegations seep away again without serious investigations, the EU runs the risk of seriously undermining its efforts and credibility in Kosovo.

\subsection{The EU as a Mediator between Belgrade and Pristina}

After the advisory opinion of the International Court of Justice (ICJ) concluded that Kosovo's declaration of independence did not violate international law, ${ }^{50}$ the EU was able to play a prominent role in influencing Belgrade to take a constructive approach. It used its influence over Belgrade to prevent a resolution calling for new status negotiations. Instead, Belgrade and the EU co-sponsored a neutral resolution, which acknowledged the advisory opinion and welcomed a dialogue between Belgrade and Pristina facilitated by the EU. ${ }^{51}$ Whereas

49 Chivvis: EU Civilian Crisis Management. The Record So Far, p. 38.

50 Cf. International Court of Justice: Accordance with International Law of the Unilateral Declaration of Independence in Respect of Kosovo, 22 July 2010 (General List No. 141), from: http://www.icj-cij.org/docket/files/141/15987.pdf $(1 / 2 / 2011)$.

51 Cf. United Nations General Assembly: Request for an advisory opinion of the International Court of Justice on whether the unilateral declaration of independence of Kosovo is in accordance with international law, New York, 13 October 2010 (A/RES/64/298), from: http://daccess-dds-ny.un.org/doc/ UNDOC/GEN/N09/479/71/PDF/N0947971.pdf?OpenElement (4/2/2011). this resolution gives rise to optimism that a negotiated solution between Belgrade and Pristina might be possible, the obstacles are still enormous.

The dialogue between Belgrade and Pristina finally started on 8 March 2011. Facilitated by Robert Cooper, Counsellor in the European External Action Service (EEAS), Borislav Stefanović, Political Director in Serbia's Ministry of Foreign Affairs, and Edita Tahiri, Deputy Prime Minister of Kosovo, have been heading delegations for a dialogue on so-called technical issues. In four rounds of official talks, Belgrade and Pristina have discussed a series of technical issues including cadastral records, birth and death certificate registries, electricity, telecommunications, participation of Belgrade and Pristina in regional organisations, custom seals, IDs and car licence plates. ${ }^{52}$ The fact that Belgrade has not recognised any documents issued by the authorities in Pristina has prevented movement of goods and people from Kosovo via Serbia with inter alia economic consequences. Moreover, participation of both Pristina and Belgrade in meetings of regional organisations such as the Central European Free Trade Agreement (CEFTA) has not been possible since Belgrade insists on Kosovar representation by UNMIK. The authorities in Pristina have not had access to cadastral records and civil registries as they have had in Belgrade. Finally, Kosovo has not been able to obtain its own country code for telecommunication while not allowing Serbian companies access to Kosovo's energy and telecommunications sector. So far, none of the above mentioned issues have been concluded with an agreement; however, both sides are optimistic that the first compromises will soon be found. ${ }^{53}$

Despite their supposedly technical nature, many of the issues raised in the negotiations have political implications. For example, it is difficult for Belgrade to accept custom seals and customs documentation that include state symbols of Kosovo as it prejudges status. In turn, compromises found inter alia on car licence plates, telecommunications and energy will require acceptance from Pristina of a continued presence of Belgrade in Kosovo, through ties between Kosovo-Serbs and Belgrade as well as through Serbian companies. Moreover, there is a high risk of politicisation of potential agreements as demonstrated for example by statements following Stefanović's recent visit to Pristina and his meetings with the Deputy Prime Ministers of Kosovo Hajredin Kuçi and Edita Tahiri: although Stefanović explicitly stated that he did not consider his visit a state visit and that it would not indicate any change in Belgrade's position on Kosovo, Thaçi presented the visit as "a beginning of new relations between Serbia and Kosovo and [...] a beginning of recognition of Kosovo." 54

The risk of politicisation of potential agreements might therefore further complicate the negotiation process and the difficult reconciliation of the contrasting positions of Belgrade

52 Cf. Marta Szpala: Relations between Serbia and Kosovo may become normalized. Warsaw, 18 May 2011, from: http://www.osw.waw.pl/en/ publikacje/ceweekly/2011-05-18/relations-between-serbia-and-kosovo-maybecome-normalised (1/6/2011).

53 Ekonom:east Media Group (EMG): Belgrade and Pristina expect certain issues to be closed, 18 May 2011, from: http://www.emg.rs/en/news/serbia/155350. html (1/6/2011).

54 B92: Belgrade, Priština voice opposite views on Kosovo visit, Belgrade, 13 May 2011, from: http://www.b92.net/eng/news/politics-article.php?yyyy=2011\& $\mathrm{mm}=05 \& \mathrm{dd}=13 \&$ nav_id=74314 $(3 / 6 / 2011)$. 
and Pristina. Both governments are in rather weak positions at home: the Serbian government is facing elections in spring 2012 and will therefore avoid making concessions that can be interpreted as a de facto recognition. At the same time, the government is considered to be counting on Serbia gaining candidate status in the EU integration process in 2011 for reelection. However, given that Serbia has met the main condition for candidate status with the arrest of Mladić, compromise with the Kosovar government might have become less central to achieve this goal. The Kosovar government, in contrast, faces strong opposition against the dialogue with Belgrade that culminated in the violent protest against Stefanović's visit to Pristina. Especially the movement Vetëvendosje! (selfdetermination), which has been the third strongest political faction in the Kosovar parliament since the elections in early 2011, strongly opposes the international presence in Kosovo and the negotiations between Belgrade and Pristina. They consider the negotiations as merely serving Belgrade's interest of gaining candidate status with nothing to gain for Kosovo. ${ }^{55}$

Given the difficult negotiation process and the need for compromise on both sides, it is all the more important that the EU finds a common approach to its role as facilitator. It needs to continue using its political leverage to set forth the process of rapprochement via dialogue about technical issues, and ensure that the parties do not terminate the talks early. Moreover, any negotiated solution will have to include a solution to the situation in the Serb-dominated north of Kosovo, as the majority of the Serb population refuses to recognise the authorities in Pristina and turns to Belgrade. While different models for solving this problem - ranging from substantial autonomy of Serb-dominated areas to the separation of Kosovo - have been discussed outside of political negotiations, ${ }^{56}$ it will be up to the EU as well as the USA to make it very clear to Pristina that they will at least have to accept a certain influence of Belgrade over parts of Kosovo in order to find a compromise.

Any compromise found, from solutions for cooperation on the technical level up to a potential solution on how Belgrade and Pristina can cooperate on a level that enables both of them to join the EU, will fundamentally help the Union to deal with Kosovo, in its engagement on the ground as well as on the political level. For example, a technical compromise with regard to the situation of rule of law in the north of Kosovo could support EULEX inter alia by solving the procedural question of appointing judges. Should the negotiations even lead to a sustainable compromise on Kosovo, the EU would finally be able to overcome its division. After all, "[o]nce Kosovo and Serbia resolve the recognition issue between themselves [...] others will have to follow suit; whatever its own opposition to independence, no state could plausibly maintain that Kosovo is de jure part of Serbia once the latter has set aside its claims." 57 However, while resolving the recognition issue does not seem realistic in

55 Cf. for example Vetëvendosje!: Newsletter from the Movement for SelfDetermination!, Pristina, 4 February 2011 ((Nr. 236), from: http://www. vetevendosje.org/repository/docs/Newsletter_Nr.236.pdf (2/6/2011).

56 For an overview over different potential solutions to the conflict cf. International Crisis Group: Kosovo and Serbia after the ICJ Opinion, Pristina/ Belgrade/Brussels, 26 August 2010 (Europe Report No206), from: http:// www.crisisgroup.org/ /media/Files/europe/206\%20Kosovo\% 20 and\%20Serbia\%20after\%20the\%20ICJ\%20Opinion-1.ashx (3/2/2011). 57 Ibid., p. 2. the short-term, the successful conclusion of the first technical compromises can establish trust between the negotiating parties as well as within their respective electorates.

Overall, while the neutral stance of the EU on the status issue can be considered important for the EU's role as facilitator, it will also need to find a way to successfully use its leverage: whereas the leverage of candidate status so far seems to be a valuable incentive for Belgrade, the impression in growing parts of the Kosovar population that Kosovo has not as much to gain from compromise as Serbia, might impair Pristina's willingness to compromise. Moreover, any compromise Pristina will have to accept will require also the support of the USA, considering its enormous influence as one of the main sponsors of Kosovar independence. Nonetheless, despite all obstacles mentioned, the facilitation of direct talks between Belgrade and Pristina seems like a unique opportunity for the EU to support both in making substantial progress, not only in the creation of regional stability by ending decades of conflict but also towards the EU, while at the same time enabling the EU to fully reunite on the Kosovo issue again.

\section{Conclusion}

As outlined above, the setup of the international engagement in Kosovo as envisaged in the Ahtisaari Plan was developed to implement independence, and the attempt to partially implement the provisions of the Plan in a status-neutral manner has resulted in the creation of parallel legal realities. As a result, supposedly technical decisions in Kosovo have become highly political ones, and slow progress as well as the EU's division over the status issue risk that incentives provided by the integration perspective for Kosovo lose credibility, especially if the Union leaves the impression that its conditionality approach is not 'strict but fair'.

The beginning of direct talks between Belgrade and Pristina facilitated by the EU has given rise to optimism. Yet, while both sides have considered the negotiations constructive, four rounds of talks have so far not had any concrete results, indicating that progress will take time. At this point it is therefore too early to tell if and to what extent the negotiations will be able to solve the recognition issue. Still, given the internal division of the EU and the lack of cohesion in its engagement in Kosovo, the EU needs to push for a compromise on Kosovo for its own sake. A compromise would not only be a chance to resolve the parallel legal realities on the ground, it could also help the EU to deal with Kosovo in the context of the SAP.

Moreover, regardless of running the risk of further losing popularity in Kosovo, the EU needs to fully investigate the allegations against Thaçi and his confidants. It is fundamental that the EU receives full support from the USA and finds the political will and the means to thoroughly investigate, as the establishment of truth is a prerequisite for reconciliation and sustainable peace. However, in light of the growing opposition against international presence in Kosovo and the talks between Belgrade and Pristina, the EU should at the same time send a signal to the Kosovar population that they are not left behind 
in the EU integration process, in order not to risk losing its leverage over Pristina. For this reason, the EU should finally provide a visa roadmap for Kosovo - not in order to lower the requirements for visa liberalisation, but in order to provide Pristina with clear guidelines for reforms. A visa roadmap would not only make the authorities more accountable in cases of shortcomings and lacking effort in the reform process; it would also send the message to the Kosovars that they too have something to gain if they work for it.
Overall, the EU needs to finally develop a more coherent and credible strategy for Kosovo in order to exercise determined leadership and live up to the responsibility it has assumed. If there is an actor that, together with its partners, has the political means to assert influence over both parties, it is the EU with its membership perspective and SAP instruments. If, however, the EU fails to find a coherent approach and finally exercise determined leadership, it will run the risk of further losing its grip on Kosovo.

\title{
Stabilization without Europeanization: Electoral Reforms in Albania
}

\author{
Judith Hoffmann*
}

\begin{abstract}
The paper looks at a challenging domestic environment for Europeanization by analysing electoral reforms in Albania. Free and fair elections have been part of the EU's political conditionality for integrating Southeast Europe since the 1990s. However, even though electoral reform remained high on the political agenda in Albania, progress in accomplishing free and fair elections was only partly achieved. Domestic political elites instrumentalised the electoral reform with the aim of getting control over state resources without consolidation democratic structures. The case of Albania shows the limits of Europeanization in transforming the institutional environment in the context of Southeast Europe.
\end{abstract}

Keywords: Europeanization, Albania, democracy, electoral reforms, political actors

Europäisierung, Albanien, Demokratie, Wahlreform, politische Akteure

\section{Introduction}

$\mathrm{R}$ esearch on post-socialist transition, by and large, regards the impact of external actors, particularly by the $\mathrm{EU}$, as successful in terms of its transfer of European norms and institutions to Central and Eastern Europe (CEE). While this perspective might hold true for the first wave of $\mathrm{EU}$ enlargement to the CEE transition countries, the effectiveness of this influence is much less obvious for the candidate and potential candidate countries in Southeast Europe (SEE) (Elbasani 2011; Grabbe 2001, 2003; Schimmelfennig/Sedelmeier 2002, 2005, 2008). Despite a growing literature, it is still not very well understood how those domestic actors strategically incorporate international norms into their local political agendas. The paper looks at the challenging environment for Europeanization in SEE analysing the area of electoral reforms in Albania.

The conduct of free and fair elections is widely seen as a minimum criterion for democracy in the transition literature. The election of a democratic government provides the first step in the dissolution of the old autocratic regime and the

Dr. Judith Hoffmann received her PhD in political science from Free University Berlin, Germany. After working as an international consultant in Albania, she was lecturer in the Euro/Transatlantic Masters program of the Berlin Graduate School of Social Sciences at Humboldt University in Berlin. Currently, she works for the German development cooperation in the Balkans, the Caucasus and in Africa. This article has successfully undergone a double-blind peerreview process. It reflects the opinion of the author only. beginning of the democratization process. As such, elections in the post-socialist transition countries received high attention by the international community, especially, the European Union and the OSCE. Free and fair elections have been part of the EU's political conditionality for the integration of SEE countries since the middle of the 1990s. They were explicitly spelled out as part of the EU's regional concept for SEE in 1997 aiming at stability and economic development. Starting from the late 1990s onwards, free and fair elections became a major EU criterion for advancing its relation with the region, which ultimately led to an integration perspective being offered at the EU Feira Summit in 2000.

The paper takes the case of Albania, a country that has been highly dependent on international support from 1991 onwards, starting its transition as the most isolated and the poorest country in SEE. It thus presents a crucial case in order to explore the absorption of international norms into the domestic system. Since the early 1990s, when Albania's transition process started, the country saw many changes in its political and economic system. The first years were rather rocky and marked by serious setbacks caused by a major state crisis after the collapse of the pyramid schemes in 1997 and the Kosovo crisis, which posed a serious risk to stability in the region and for Europe. Since then, many steps have been taken in bringing Albania closer to a democracy and market economy. Intriguing in the case of Albania is that even though we can observe considerable reform measures being taken towards the 